\title{
モルタルの粘弾性挙動に関する基礎的研究 (その2)
}

（粘性を考慮した場合の非破壊試験法に依る強さ推定について）

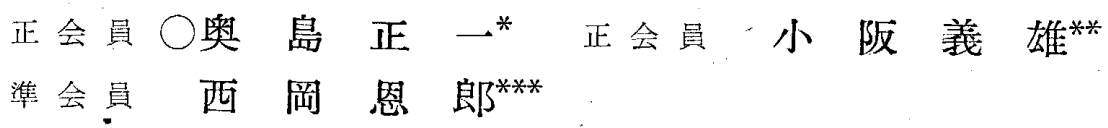

\section{$\S 1$. 序}

モルタルの粘弾性挙動虾適当な力学的模型に依つて表 はされる。そしてこの力学的模型の最も基本的型態は弾

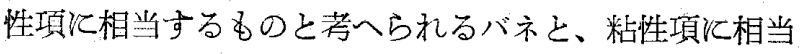
するものと考へられるダッシュポットを直列或いは並列 に結合した所謂、Maxwell 型或いは Voight 型である がコンクリートやモルタルの場合はこれらの基本型を更 に適当飞組合せた混合型に依つてその力学的性状がより 良く表わされると云われている1)。然し乍ら、模型の型 が複雑化する程、こうしたモデルから成る材料の振動性 状の解析式の諸常数を決定するための実験方法が困難と なるのである。

こうした困難を避けるため、Kesler·Higuchi 両氏は 粘性係数它直接測定する代りに供試体の撓み振動から対 数減衰率を測定し、これと共振法に侬り測定される動的 ヤング係数とを併用してモルタルの圧縮強さ（以下これ を単炕強さと記す）を可成りの精度で推定し得ることを 述べた2゙。

然し乍ら、前報了で述べた如くモルタルの力学的模型 として最も簡単な Maxwell 型を想定し振動試験とよつ てこのモデルの常数、即ちヤング係数 $E$ と粘性係数 $\eta を$ 求めると, それらは同一供試体について行つた静的載荷 試験による応力度 $\sigma$ と歪度 $\varepsilon$ との関係を表はす実験式

$$
\varepsilon=A \cdot \sigma+B \cdot \sigma^{2}
$$

の常数 $A, B$ の値との間膤めて良好な相関を有する事

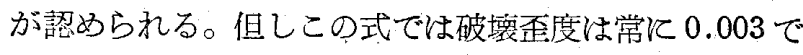
あるものと仮定してある。従つてモルタルの破壊条件と してその破壊歪度がある一定の大きさとなるものと考へ ると、振動試験依り求めた $E, \eta$ の值加 $A, B$ の值 を推定する事依り（1）式からその破壊強さを推定する 事妿出来る事となる。

本論文はこの方法俍つて推定した破壊強さと、従来 筆者等が発表した如きモルタル中を伝わる音速 $V$ 或いは 動的中ング係数 $E$ のから推定した破壊强さとを比較し て、どの程度の推定精度を示すかを比較検討する意味で 行つた基礎的な実験の報告である。更とコンクリート或 い经村令の異つた場合等についてもつと広範な実験研究 觉行い、初めて本試験方法の最終的な当否が決定される

\footnotetext{
* 大阪大学教授 工博 *关大阪大学助教授 ***大陏大学大学院学生
}

べきであると思はれるが、一応この方向への一段階とし て、基礎的な実験を行つた結果を報告する事とした。

\section{§2. 研究方針}

種々の非破壊試験法に依る推定強さの当否の判定に は、強さ推定式に対する実験檤の散らばり程度を調べて 比較するのが最も簡便ではあるが、ここで述べる推定方 法では推定に際して仮定すべき係数が二つ入つて来るの で直接これらの散らぼりを示す事が出来なかつた為、次 の如き方法を取る事とした。

先つ強さを推定する方法として、次の 3 種の方法依 ることとする。即ち、

（a）超音波法に依つてモルタル供試体の中学伝はる 音速 $V$ を実測しこれと破壊強さ $\sigma$ との值より $V-\sigma$ の関 係を示す実験曲線を求め、この実験曲線によつて $V$ の 実測值からのの值を推定する。

（b）共振法に依つてモルタル供試体のEを実測し、 乙れ之破壊強さ $\sigma$ との值より $E-\sigma$ の関係を示す実験曲 線求め、この曲線依つて $E$ の実測值から $\sigma$ の值を推 定する。

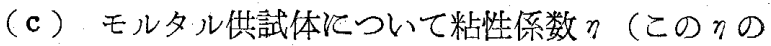
求め方については、前報を参照されたい)を測定し、こ れと上記 ( $\mathrm{b}$ )の場合飞得られたヤング係数 $E$ の值を夫々 次の (2),(3) 式に代入する事に依り常数 $A, B$ を計算 する。

$$
\begin{gathered}
\log 1 / E=0.9347 \cdot \log A-0.4088 \\
\log 1 / \eta=0.3605 \cdot \log B+0.2090 \\
\text { ここに } E ; \quad \text { ヤング係数 }\left(\mathrm{kg} / \mathrm{cm}^{2}\right) \\
\eta ; \quad \text { 粘性 係数 }\left(\mathrm{kg} \cdot \mathrm{sec} / \mathrm{cm}^{2}\right)
\end{gathered}
$$

但し (2)，(3) 式は実験的に求めた式であつて、これ そついては前報で述へて怙いた。かくして得られた常数 $A, B$ を(1) 式代入し、问（1）式の $\varepsilon$ の値として $\varepsilon=0.003$ を取つてこれょり破壊強さ $\sigma$ 算出する。

次化、以上 3 方法より夫久推定し得る破攘強さの程度 を比較するためにこれら三つの方法を同一のモルタル供 試体に適用して実際の強さに対する推定強さの誤差を比 較検討する。

\section{§3. 実験方法}

供試体 試験と用いたモルタルの供試体は、直径 $10 \mathrm{~cm}$ 高さ $20 \mathrm{~cm}$ の円柱型で、その調合比は $1: 2 \sim 1: 3.5$, 水 比は 50\% 95\%、材令は 28 日でこれらの值及び使用材 
料、養生等は前報に述べた如くである。

$E, \eta$ の測定これらはいら゙れる前報の如く、共振法に 依つて測定した。

$V$ の測定 $V$ 以筆者等が従来使用している超音波装置 飞依り測定した。 $\sigma, \varepsilon$ の湘定 $\sigma, \varepsilon$ の測定ね前報て述べた通りである。

\section{§4. 実験結果及び考察}

実験依つて求められた $V, E, \eta, A, B$ 等は前報にも 述べたが、読者の便をねかりここ第 1 表として再録す る。

第 1 表

\begin{tabular}{c|c||c|c|c|c|c|c}
\hline 配 合 & 水比 $\%$ & $E \times 10^{5} \mathrm{~kg} / \mathrm{cm}^{2}$ & $1 / E \times 10^{-5} \mathrm{~cm}^{2} / \mathrm{kg}$ & $\eta \times 10^{3} \mathrm{~kg} . \mathrm{sec} / \mathrm{cm}^{2}$ & $1 / \eta \times 10^{-3} \mathrm{~cm}^{2} / \mathrm{kg} \cdot$ & $V \mathrm{~km} / \mathrm{sec}$ & $\sigma \mathrm{kg} / \mathrm{cm}^{2}$ \\
\hline $1: 2$ & 50 & 3.30 & 0.303 & 0.502 & 1.99 & 3.83 & 444 \\
$\prime \prime$ & 55 & 3.09 & 0.324 & 0.492 & 2.04 & 3.79 & 414 \\
$\prime \prime$ & 60 & 3.00 & 0.333 & 0.482 & 2.07 & 3.66 & 403 \\
$\prime \prime$ & 65 & 2.82 & 0.355 & 0.435 & 2.30 & 3.65 & 379 \\
\hline $1: 2.5$ & 60 & 3.08 & 0.325 & 0.449 & 2.23 & 3.80 & 371 \\
$\prime \prime$ & 65 & 3.04 & 0.329 & 0.416 & 2.41 & 3.67 & 358 \\
$\prime \prime$ & 70 & 2.78 & 0.360 & 0.365 & 2.74 & 3.62 & 305 \\
$\prime \prime$ & 75 & 2.65 & 0.377 & 0.334 & 2.99 & 3.57 & 230 \\
\hline $1: 3$ & 65 & 2.91 & 0.344 & 0.412 & 2.42 & 3.67 & 347 \\
$\prime \prime$ & 75 & 2.67 & 0.375 & 0.368 & 2.72 & 3.55 & 260 \\
$\prime \prime$ & 85 & 2.47 & 0.405 & 0.218 & 4.58 & 3.37 & 160 \\
\hline $1: 3.5$ & 75 & 2.60 & 0.385 & 0.334 & 2.99 & 3.44 & 236 \\
$\prime \prime$ & 85 & 2.41 & 0.415 & 0.220 & 4.55 & 3.37 & 170 \\
$\prime \prime$ & 95 & 2.09 & 0.478 & 0.159 & 6.28 & 3.27 & 131 \\
\hline
\end{tabular}

但し表中の值はすべて供武体 3 個の平均值をるつて表 はされている。劣 $\eta$ を求める為に必要な対数減衰率とし て最大振门の $1 / \sqrt{2}$ 倍の位置泛於ける值を取つた。

さて第一表の値より $V-\sigma$ の関係を図示すれば第 1 図

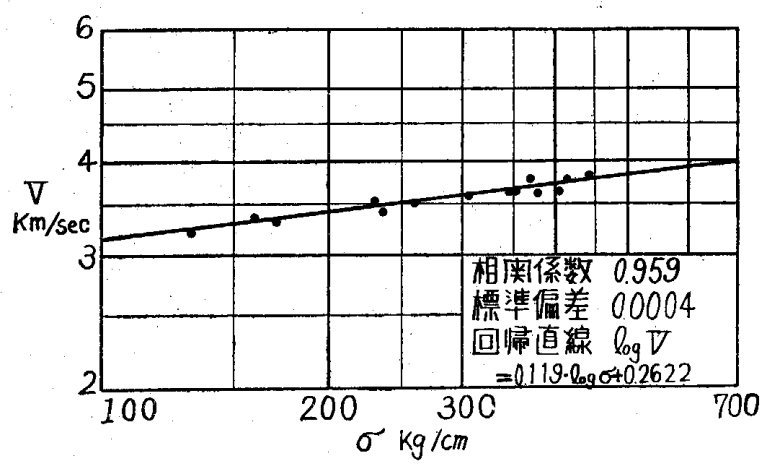

第 1 図

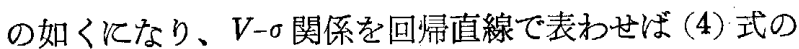
如くなる。

$$
\begin{aligned}
\log V=0.119 \cdot \log \sigma+0.2622 \\
\text { ここに } V ; \text { 音速 }(\mathrm{km} / \mathrm{sec}) \\
\sigma ; \text { 破壊強さ }\left(\mathrm{kg} / \mathrm{cm}^{2}\right)
\end{aligned}
$$

䏌図中に相関係数及び回帰直線に対する $V$ の値の標準 偏差を記入して置いた。この (4) 式に依れば、Vの值よ りのを求める事が出来る。
又 $E-\sigma$ の関係は第 2 図の如くになり、これらの実測

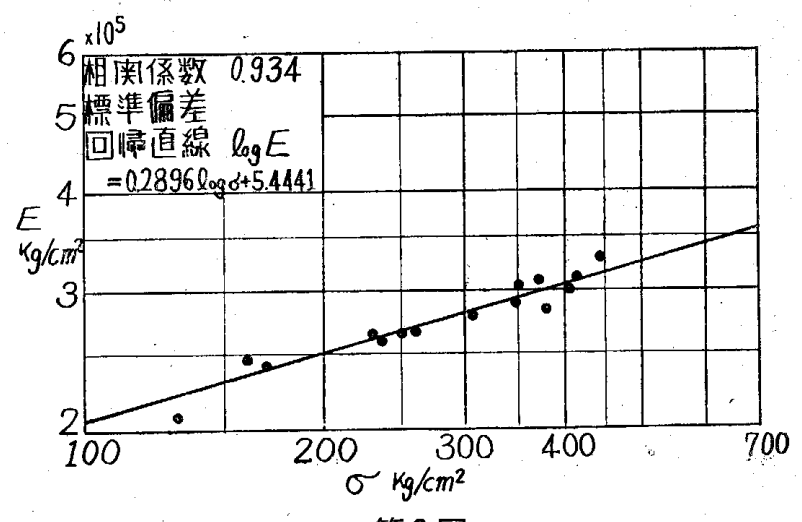

第 2 図

值と対する回帰直線は (5) 式の如くなる。

$$
\log E=0.2896 \cdot \log \sigma+5.4441
$$

ここと $E$; ヤング係数 $\left(\mathrm{kg} / \mathrm{cm}^{2}\right)$

$$
\sigma \text {; 破壊強さ }\left(\mathrm{kg} / \mathrm{cm}^{2}\right)
$$

第 2 図には相関係数及び回州直線汶対する $E$ の值の標準 偏差を記入して置いた。この (5) 式に依孔ば、Eの值よ り。を求める事が出来る。

次に $E$ 及び $\eta$ の実測值を用い（2）式及び (3) 式か $ら A$ 及び $B$ の值を計算すると、それらの値は第 2 表の如 くなる。 
第 2 表

\begin{tabular}{c|c||l|l}
\hline 配 合 & 水 比 \% & $A \times 10^{-5}$ & $B \times 10^{-7}$ \\
\hline $1: 2$ & 50 & 0.333 & 0.079 \\
$\prime \prime$ & 55 & 0.388 & 0.084 \\
$\prime \prime$ & 60 & 0.388 & 0.089 \\
$\prime \prime$ & 65 & 0.421 & 0.098 \\
\hline $1: 2.5$ & 60 & 0.363 & 0.123 \\
$" \prime$ & 65 & 0.366 & 0.139 \\
$" \prime$ & 70 & 0.398 & 0.193 \\
$\prime \prime$ & 75 & 0.415 & 0.390 \\
\hline $1: 3$ & 65 & 0.406 & 0.141 \\
$\prime \prime$ & 75 & 0.417 & 0.278 \\
$\prime \prime$ & 85 & 0.454 & 0.887 \\
\hline $1: 3.5$ & 75 & 0.457 & 0.348 \\
$" \prime$ & 85 & 0.491 & 0.767 \\
$\prime \prime$ & 95 & 0.533 & 1.339 \\
\hline
\end{tabular}

これらのA及び $B$ の值と $\varepsilon=0.003$ とを(1) 式に代入 乙て求めた破壊強さの值を $\sigma_{1}$ （計算図 表第 3 図から

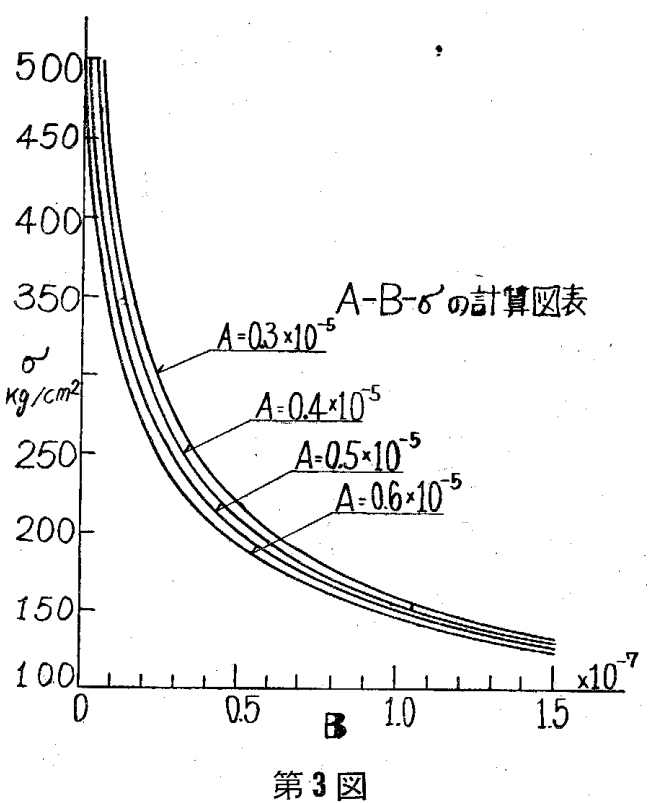

計算する事が出来る)とし、(4) 式及び (5) 式の夫々に $V$ 及び $E の$ 值を代入して求めた破壊強さの值を夫々 $\sigma_{2}, \sigma_{3}$ 上 し、破壊強さの実測值を $\sigma_{0}$ とすると、 $\sigma_{1}, \sigma_{2}, \sigma_{3}$ の値及 び $\sigma_{0}$ に対する $\sigma_{1}, \sigma_{2}, \sigma_{3}$ の比は第 3 表の如くなる。

第 3 表

\begin{tabular}{|c|c|c|c|c|c|c|c|c|}
\hline 配合 & 水比％ & $\sigma_{0} \mathrm{~kg} / \mathrm{cm}^{2}$ & $\sigma_{1} \mathrm{~kg} / \mathrm{cm}^{2}$ & $\sigma_{2} \mathrm{~kg} / \mathrm{cm}^{2}$ & $\sigma_{3} \mathrm{~kg} / \mathrm{cm}^{2}$ & $\sigma_{1} / \sigma_{0}$ & $\sigma_{2} / \sigma_{0}$ & $\sigma_{3} / \sigma_{0}$ \\
\hline $1: 2$ & 50 & 444 & 428 & 488 & 521 & 0.97 & 1.10 & 1.17 \\
\hline " & 55 & 414 & 412 & 447 & 415 & 1.00 & 1.08 & 1.00 \\
\hline$"$ & 60 & 403 & 400 & 334 & 375 & 0.99 & 0.83 & 0.93 \\
\hline$"$ & 65 & 379 & 356 & 326 & 302 & 0.94 & 0.86 & 0.80 \\
\hline $1: 2.5$ & 60 & 371 & 382 & 457 & 411 & 1.03 & 1.23 & 1.11 \\
\hline " & 65 & 350 & 352 & 342 & 392 & 1.01 & 0.98 & 1.12 \\
\hline$"$ & 70 & 305 & 296 & 304 & 288 & 0.97 & 1.00 & 0.94 \\
\hline$" \prime$ & 75 & 230 & 266 & 271 & 244 & 1.16 & 1.18 & 1.06 \\
\hline $1: 3$ & 65 & 347 & 342 & 342 & 337 & 0.99 & 0.99 & 0.97 \\
\hline$" 1$ & 75 & 260 & 296 & 258 & 250 & 1.14 & 0.99 & 0.96 \\
\hline " & 85 & 160 & 163 & 167 & 192 & 1.02 & 1.04 & 1.20 \\
\hline $1: 3.5$ & 75 & 236 & 264 & 199 & 229 & 1.12 & 0.84 & 0.97 \\
\hline " & 85 & 170 & 164 & 169 & 176 & 0.97 & 0.99 & 1.04 \\
\hline " & 95 & 131 & 108 & 130 & 108 & 0.83 & 0.99 & 0.83 \\
\hline
\end{tabular}

又第 3 表の結果より各種の強さ推定法に於ける推定誤 差の分布状態を表示すれば第 4 表又は第 4 図の如くな

り、推定強さの請差は $\sigma_{1}$ が最も小さく、それ次いで

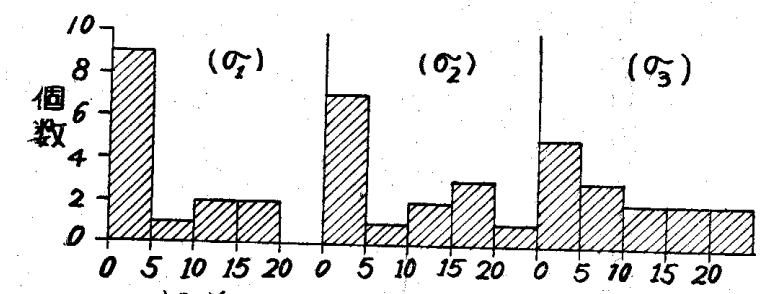

誤差 \%

\begin{tabular}{l|l|l|l} 
& \multicolumn{2}{|c|}{ 第 4 表 } \\
\hline 誤差 & $\sigma_{1}$ & $\sigma_{2}$ & $\sigma_{3}$ \\
\hline $0 \%$ 以上 & 9 個 & 7 個 & 5 個 \\
\hline $5 \%$ 以上 & $1 \prime$ & $1 \prime$ & $3 \prime \prime$ \\
\hline $10 \%$ & $2 \prime \prime$ & $2 \prime \prime$ & $2 \prime \prime$ \\
\hline $15 \%$ 以上 & $2 \prime \prime$ & $3 \prime \prime$ & $2 \prime \prime$ \\
\hline $20 \%$ 以上 & $0 \prime \prime$ & $1 \prime \prime$ & $2 \prime \prime$ \\
\hline 誤差平均 $\%$ & 5.9 & 8.3 & 9.3 \\
\hline
\end{tabular}


$\sigma_{2}, \sigma_{3}$ の順となる事が認められる。

モルタル又はコンクリート中の音速は、理論的には低 応力時のヤング係数に支配され、一方このヤング係数は モルタル又はコンクリートの破壊強さと依り支配される から、一灾音速又はヤング係数の值はモルタル又はコン クリートの破壊強さを推定する要素となる。然し、音速 は材料のヤング係数の他にポアソン比江依つても左右さ れ、その上このポアソン比の数值てついては侗不明確で ある為、この数値を仮定して音速からヤング係数を算出 してもとの精度については问疑問の点が存在する。文た そへ正確なヤング係数が得られたとしても、低応力時の ヤング係数の大小から直らにモルタル页はコンクリート の破嘼強さの大小を判断し得るとは限らない。換言すれ ば、ヤング係数の大なるものの破壊強さがヤング係数の 小なるるのよりる低い場合のある事が実験的に認められ るのである。

従つてヤング係数と压縮強さとを直結せしめる事は無 理であつて、ぞうしてもここに述べた椂に粘性項を考慮 する必要を生ずる事となる、かかる理由で、従来筆者等 の発表した音速又はヤング係数のみから強さを推定する 方法は、かなりの䛊差を含んでいたが、これに対し、こ こに述べた如き粘珄を考虑した推定方法は従来の方法よ り一步進えだ推定方法という事が出来よう。尤も、この 実験は極て一部の種類の㤨試体について行はれた結果で あるため、更にモルタル、コンクリートについてとの調 合、水比、材命、養生方法等を変化せしぬて広範囲の実 験を行う必要があり、その場合にも上述の如き結果が得 られる迄はこの方法が最良であると判定し得ない事は云
ろまですなからう。

\section{§. 結 語}

モルタル或いはコンクリートの非破鲛試験に於て、筆: 者等洋来低応力時のヤング係数の数值を用いてその破 壊強さの推定を行つて来たのであるが、このヤング係数 の大小と、破壊強さの大小との間には判然とした関係が ないためその推定誤差がある程度生ずる事は避け得られ。 なからた。

これに対し、ここに述ベた如きモルタル刃はコンクリ 一トの粘性を考慮する方法は、かなりモルタル、コンク リートの応力度一歪度の関係をよく示すため、破鈸強さ の推定際して推定㕵差の精度がより良くなると思はれ， る。

然し、本報に示した方法では、低応力時のャング係数. と粘性係数の数值を必要とし、一方実施コンクリートで は常にこれらの数值を測定し得るとは限らない。実施コ ンクリー・・の非破䏅試験法では、超音波法の応用が便利 であると考へられるから、今後、この超音波法に依り如 何にしてヤング係数と粘性係数を求めるかが研究課題と ならう。

[参考交献]

(1) "Nichtelastische Verzerrungen des Betons." Der Bauing 1953. Hft 10

(2) Kesler.Higuchi "Determination of compressive strength "of concrete By using its. sonic Properties" A.S.T.M. 1953

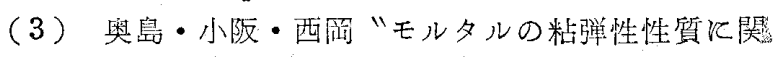
する基礎的研究その(1)” 